\title{
MEDICINE
}

\section{PATHOGENETIC FEATURES OF SOLIDARITY OF INTERDEPENDENCE AND INTERACTION OF GENERALIZED PARODONTAL DISEASES AND ANOREXIA NERVOSA}

\author{
${ }^{1}$ Professor Maryna Antonenko, doctor of Medicine, \\ ${ }^{2}$ PhD Natalia Zelinska, \\ ${ }^{3} \mathrm{PhD}$ student Lujdmila Reshetnyk, \\ ${ }^{4} \mathrm{PhD}$ Roman Popov, \\ ${ }^{5}$ PhD student Valentyna Slavinskaya \\ Ukraine, Kiev, \\ ${ }^{1}$ Head of Department of Dentistry, Institute of Postgraduate Education, Bogomolets National Medical \\ University; \\ ${ }^{2}$ Department of Dentistry, Institute of Postgraduate Education, associate professor; \\ ${ }_{3,5}^{3}$ Department of Dentistry, Institute of Postgraduate Education, PhD student; \\ ${ }^{4}$ Department of Dentistry, Institute of Postgraduate Education, assistant professor
}

\section{DOI: https://doi.org/10.31435/rsglobal_ws/31012020/6892}

\section{ARTICLE INFO}

Received: 22 November 2019

Accepted: 15 January 2020

Published: 31 January 2020

\section{KEYWORDS}

generalized parodontal diseases, generalized parodontitis,

hypersensibilisation, anorexia nervosa, osteoporosis. \begin{abstract}
The study was aimed to establish the features of configuration of generalized parodontal diseases and their clinical manifestations in the format of basic characteristics of anorexia nervosa. We used clinicoradiological, immunological, analytical and statistical methods. Thus, direct correlation and interdependence of generalized parodontal diseases in the format of basic characteristics of anorexia nervosa were established.
\end{abstract}

Citation: Maryna Antonenko, Natalia Zelinska, Lujdmila Reshetnyk, Roman Popov, Valentyna Slavinskaya. (2020) Pathogenetic Features of Solidarity of Interdependence and Interaction of Generalized Parodontal Diseases and Anorexia Nervosa. World Science. 1(53), Vol.1. doi: 10.31435/rsglobal_ws/31012020/6892

Copyright: () 2020 Maryna Antonenko, Natalia Zelinska, Lujdmila Reshetnyk, Roman Popov, Valentyna Slavinskaya. This is an open-access article distributed under the terms of the Creative Commons Attribution License (CC BY). The use, distribution or reproduction in other forums is permitted, provided the original author(s) or licensor are credited and that the original publication in this journal is cited, in accordance with accepted academic practice. No use, distribution or reproduction is permitted which does not comply with these terms.

Introduction. Generalized parodontal diseases (GPD) are one of the most common dental diseases, which occupy a significant place in the structure of human diseases [1]. Recently, there has been a steady tendency to increase the prevalence of GPD not only among able-bodied, but among young people with no gender preferences. According to WHO, the prevalence of GPD is 60-90\% [2].

Despite the increase in dental culture of the population, which has been trending lately and prompts the early treatment of patients, the result of treatment of GPD is often unsatisfactory. This is due to some extent because of the complexity of understanding the etio-pathogenetic mechanisms of development of these diseases, and the high association of GPD with a number of diseases of the internal organs and systems with common points of contact between interdependence and mutual influence [3].

A great number of researchers point to the high probability of pathogenetic communication of GPD with endocrine pathology, systemic diseases of human connective tissue, infraction vitamin, protein and lipid metabolism, emphasizing the thesis of associativity, affiliation and, even, the comorbidity of these diseases in patients with such basic pathology $[4,5]$. But in literature there are only fragmentary science 
articles that suggest a possible correlation of anorexia nervosa (AN) and GPD and offer a specific approach to the features of their treatment, which, in our opinion, is a major drawback [ 6, 7].

Recently, the incidence of AN has increased significantly and poses a serious state, social, psychological and medical problem. According to WHO in the general population, the prevalence of AN ranges from 0.37 to 1.0 per 100,000 population, with a frequency of $0.9-4.3 \%$ in women and $0.3 \%$ in men and tends to increase significantly $[8,9,10]$. A particularly high risk of death was found with critically low body weight and later onset $[11,12,13]$.

There are significant changes, associated with AN, in the neuro-endocrine system, including the axis of the hypothalamus - pituitary - amygdala - genital and thyroid gland. These changes are accompanied by a decrease in estrogen production, leading to pre-menarcheal amenorrhea and potentiating cortisol levels, abnormal secretion of insulin-like growth factor-1 and decreased thyroid hormone metabolism. Hypoestrogenia can be a trigger for the development of osteopenia and osteoporosis, which leads to a decrease in bone mineral density. Emerging hypogonadism and secondary hyperparathyroidism, as a result of disorganizing eating behavior in AN, low calcium intake, and vitamin D deficiency and hypercorticism, may also be one of the important components that predispose GPD in patients with AN.

Absence of clear ideas about interaction and interaction do not allow to develop adequate methods of treatment of GPD in patients with AN.

Aim: To establish the features of the configuration of generalized periodontal diseases and their clinical manifestations in the format of basic characteristics of anorexia nervosa.

Tasks: 1 . To establish frequency, clinical and radiological markers of generalized parodontal diseases in patients with anorexia nervosa.

2. To study the degree of cooperation of age, gender, duration and form of anorexia nervosa with generalized parodontal diseases.

3. To present our view of the paradigm of interaction of affiliation and comorbidity of generalized parodontal diseases and anorexia nervosa.

Materials and methods: to achieve this goal, clinical and radiological methods of parodontal assessment were used to verify the diagnosis (according to the systematics of parodontal diseases after M.F. Danilevsky, 1994) as well as immunological tests (inhibition of migrating leukocytes) by M. George method as a first type screening reaction and statistical methods (STATISTICA 6.0).

The object of our research, with informed consent, included 75 patients with AN, 18-36 years (average age $26 \pm 3.8$ ) - the main group $(\mathrm{M})$, and 60 patients without AN of the same age - the comparison group (C). For a detailed analysis of the clinical manifestations of GPD all patients in the main (M) and comparative (C) groups were divided into several subgroups. $\mathbf{M}_{1}$ subgroup - patients with various forms of gingivitis. The $\mathrm{M}_{2}$ subgroup included patients with generalized parodontities (GP), associated with AN as the basic pathology.

The comparative (C) group consisted of two subgroups $\left(\mathrm{C}_{1}\right),\left(\mathrm{C}_{2}\right)$ with different forms of gingivitis and GP, respectively. All patients with AN had a treatment in the neuropsychiatric department of Kiev Clinical Hospital on railway transport №1 (head of the Department O.V. Moskalenko). Note, that all examined patients had a restrictive form of AN. We did not have patients with the cleansing form of AN.

Results of own research. The research, as a whole, established a high incidence of GPD in patients with AN, including both independent soft parodontal tissue diseases and diseases of the entire parodontal complex (Fig. 1.).

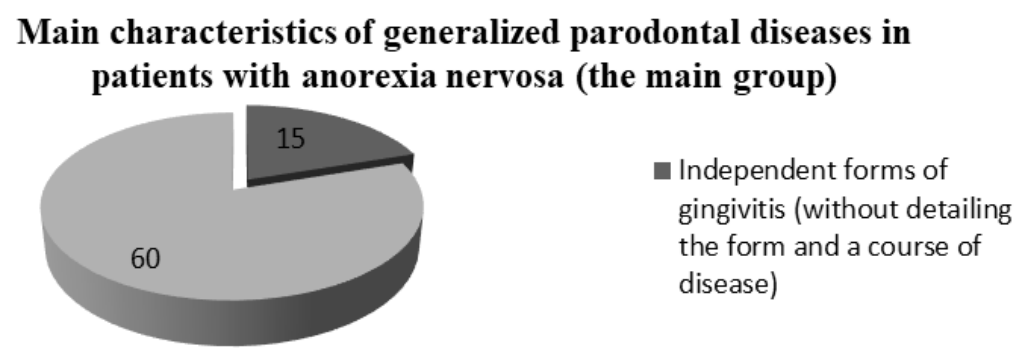

Fig. 1.

In the result of the research, independent parodontal soft tissue diseases of various forms and the course of gingivitis were diagnosed in $20 \pm 4.6 \%$ cases, while GP of different degrees and course was observed in $80 \pm 4.6 \%$ in the main group. 
It should be noted that patients of the comparative group without manifestations of anorexia nervosa had a higher incidence of independent forms of gingivitis - $80 \pm 5,2 \%$, while GP of different degrees and course was diagnosed less frequently and was observed in $20 \pm 5,2 \%$ of cases (Fig. 2.).

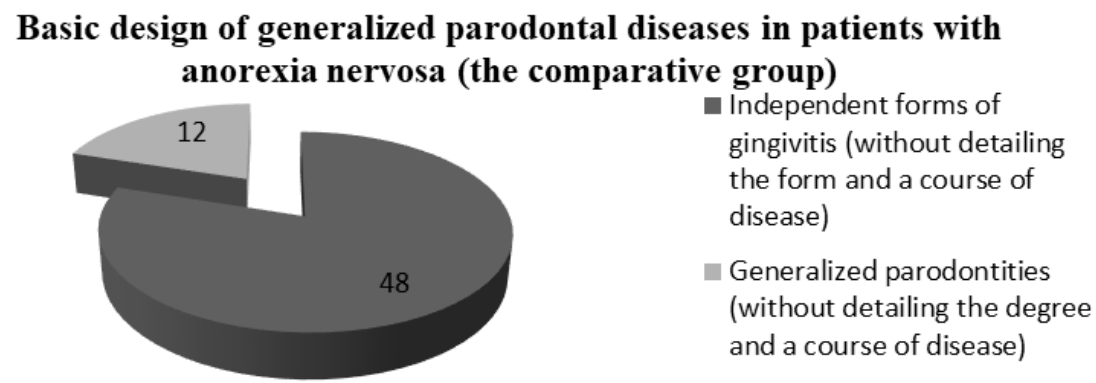

Fig. 2.

Analyzing the data of patients of the subgroup $\mathrm{M}_{2}$, catarrhal gingivitis prevailed among the independent diseases of the soft parodontal tissues, while other forms of gingivitis were not diagnosed.

It was found that the majority of patients had catarrhal gingivitis in $86.7 \pm 8.8 \%$ cases, which had exclusively chronic course, and exacerbation of the process was observed only in $13.8 \pm 8.8 \%$ cases.

It is fair to note that the collection of a detailed anamnesis in patients of the main group and the identification of complaints was difficult due to the lack of a psychological alliance, which was accompanied by a lack of willingness to participate in voluntary contact during the examination. This is due to the fact that people with AN are unreliable "informants". Only a further structured interview helped gather information to evaluate anamnestic features and complaints.

While examination patients of the (C) group collection of anamnesis and complaints had no difficulties. Such patients were ready for dialogue. There was an open desire to participate in a therapeutic alliance.

We believe that the absence of any connotative dental complaints in patients of (M) group, in our opinion, could be due to the full focus only on the paradigm of their appearance, pathological concern about their own weight, figure and low level of all components of compliance. But in $20 \pm 10.3 \%$ of cases there was a so-called symptom of aeration, manifested by complaints of the inability to chew food, unbearable pain when trying to bite off a piece of fresh bread, "pathological tooth mobility" and a feeling of tooth loss that did not respond to clinical changes.

It should be noted that in the majority of patients of $\mathrm{M}_{1}$ subgroup chronic gingivitis was characterized by involvement in the pathological process of only the marginal part of the gums. In most cases $(66.7 \pm 12.2 \%)$ with a background of stagnant hyperemic and dense gums, a marked narrow band of stagnant hyperemia was noted in the area of the cervical teeth. In $20 \pm 10.3 \%$ cases areas of congestive gum hyperemia were replaced by zones with marked pallor. It was found that only $13.8 \pm 8.8 \%$ cases of chronic inflammation covered all components of the soft tissues of the periodontium.

Patients in $\mathrm{M}_{1}$ subgroup had typically supragingival dental calculus, and in $26.7 \pm 11.4 \%$ cases it appeared as a whole layer.

In all patients of the $\mathrm{M}_{1}$ subgroup according to the radiological examination, the extension of periodontal fissures was established throughout, while maintaining the cortical plate. They noted osteoporosis of the apex of the alveolar bone ridge and bone components of the periodontal complex.

It can be assumed that the enlargement of the periodontal cleft and osteoporosis, on the one hand, was due to chronic inflammatory process in the soft tissues of the parodontum, and on the other - the existing osteoporosis could be a manifestation of systemic osteoporosis caused by a decrease in estrogen production, abnormal secretion of insulin secretory factor and decreased thyroid hormone metabolism, resulting hypogonadism, and secondary hyperparathyroidism.

Patients of the $C_{1}$ subgroup, unlike pations of the $M_{1}$ subgroup, were diagnosed with all forms of gingivitis, including catarrhal, atrophic, desquamative, ulcerative-necrotic and hypertrophic, accounting for $77.1 \pm 6.1 \%$ cases, $4,2 \pm 2.9 \%$ cases, $6.3 \pm 3.5 \%$ cases, $2.1 \pm 2.1 \%$ cases, $10.4 \pm 4.4 \%$ cases, respectively.

It should be noted that, unlike the patients in the (M) group, in the (C) group, a high motivational component was observed, which indicated a willingness to take part in full treatment.

Finalizing the analysis of subjective and clinical manifestations of lesions of parodontal soft tissues affiliated with AN, the patients of the (M) group were characterized by: no complaints; low degree of psychological alliance with the doctor; had catarrhal gingivitis with a predominant lesion of 
the marginal gums with chronic course; extension of the periodontal cleft and osteoporosis of the bone component of the periodontal complex.

In 60 patients $(80,0 \pm 4,6 \%)$ (out of 75$)$ of the $\left(\mathrm{M}_{2}\right)$ subgroup on the basis of clinical and radiological examination was diagnosed GP from the initial to the second degree, chronic course with the predominant absence of complaints (Fig. 3.).

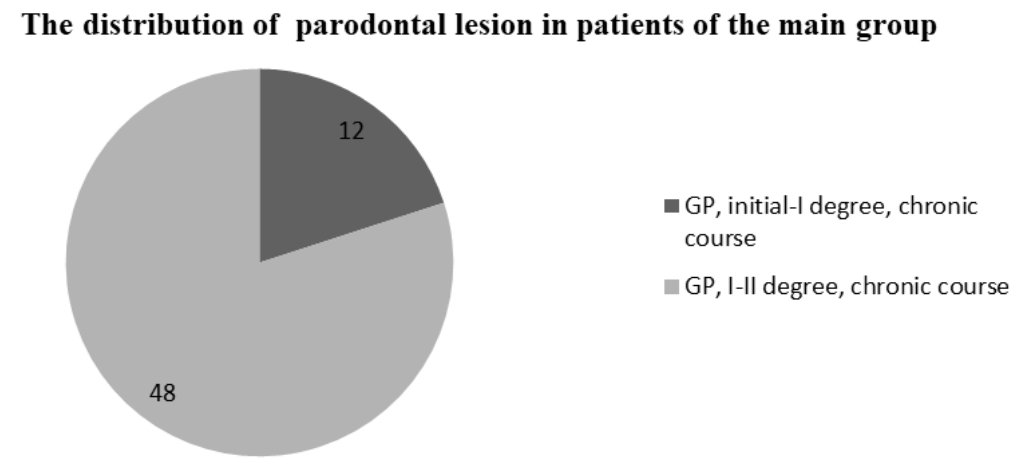

Fig. 3.

It should be noted that among the examined patients of the $\mathrm{M}_{2}$ subgroup, GP had a chronic course, and only $3.3 \pm 2.3 \%$ cases had exacerbation of the process as a result of the recently transmitted infectious process. Symptomatic catarrhal marginal gingivitis was observed in soft periodontal tissues. We believe that mainly chronic course of GP in patients of $\mathrm{M}_{2}$ subgroup, in our opinion, could be caused by significant changes in the general immunological reactivity of the organism due to AN, which did not allow to trigger an active inflammatory response.

As a result of radiological examination of patients of $\mathrm{M}_{2}$ subgroup with primary $-\mathrm{I}$ degree $\mathrm{GP}$, the extension of the periodontal fissure and osteoporosis of the bone component of the periodontal complex was revealed, the horizontal type of resorption in all patients, as well as the cortical plate dislocation in the segment of the primary degree, and 1/3 reduced in the segment I degree. The advantages and priorities of different segments of the periodontal complex in patients with NA were not observed.

In determining the hypersensitivity of the delayed action to the bone antigen in this group, all patients showed a high degree of tissue sensitization, which showed significant changes in the bone component of the parodontal complex. This could be a predictor and an indicative factor that simplifies the diagnosis of primary-stage GP when the radiographic picture is not yet clearly expressed.

Some peculiarities were established in the study of the interdependence of GPD and AN with the gender of patients, age and their peculiarities of duration, form and stage of the main disease.

Thus, no influence of gender on the peculiarities of manifestation of GPD, associated with AN was noted (Fig. 4.).

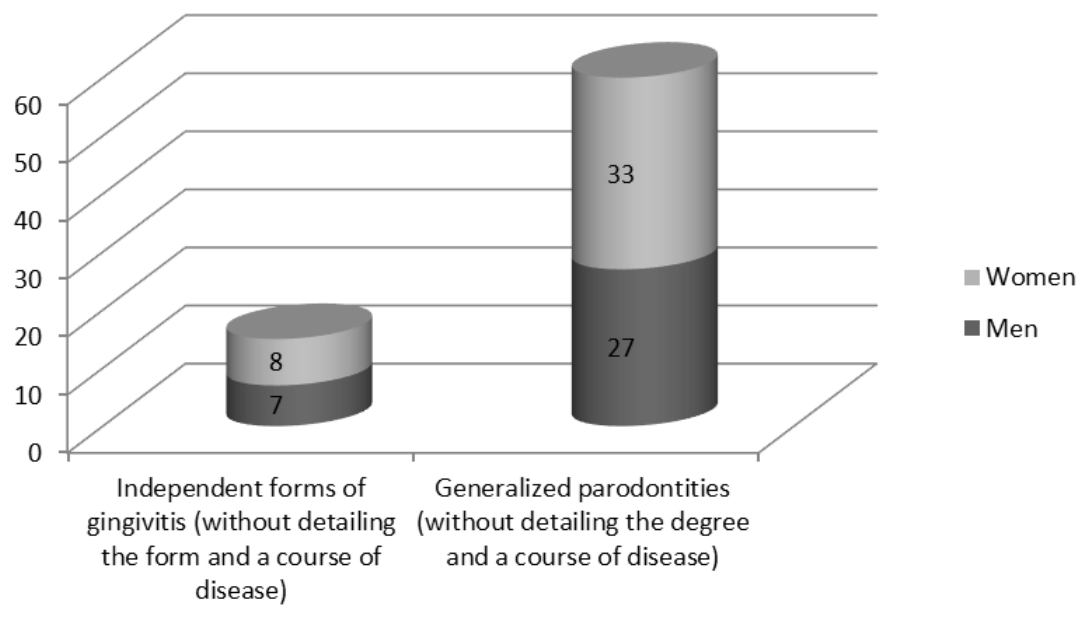

Fig. 4. The impact of patients gender with anorexia nervosa on the features of the course of generalized parodontal diseases

It was found that high frequency of GPD was defined to all age categories of patients with $\mathrm{AN}$, and the course of GP increased with age (table 1). It should be noted that since the exacerbated course of both catarrhal gingivitis and GP was observed in 2 persons, respectively, we considered it 
expedient to analyze the effect of patients' age on the frequency of GPD only among persons with GPD chronic course, associated with AN.

Table 1. Influence of age on frequency of generalized parodontal diseases in patients with anorexia nervosa

\begin{tabular}{|c|c|c|c|c|}
\hline \multirow[t]{2}{*}{ Main disease } & \multirow{2}{*}{$\begin{array}{c}\text { Age of } \\
\text { patients, years }\end{array}$} & \multirow{2}{*}{$\begin{array}{l}\text { Catarrhal gingivitis, } \\
\text { chronic course }\end{array}$} & \multicolumn{2}{|c|}{ Generalized parodontal diseases } \\
\hline & & & $\begin{array}{l}\text { GP, initial-I degree, chronic } \\
\text { course }\end{array}$ & $\begin{array}{l}\text { GP, I-II degree, } \\
\text { chronic course }\end{array}$ \\
\hline \multirow[t]{3}{*}{ Anorexia nervosa } & $18-25$ & $\begin{array}{c}7 \\
9,9 \pm 3,5 \% \\
P>0,05\end{array}$ & $\begin{array}{c}8 \\
11,3 \pm 3,8 \% \\
P>0,05\end{array}$ & $\begin{array}{c}11 \\
15,5 \pm 4,3 \% \\
P>0,05\end{array}$ \\
\hline & $25-30$ & $\begin{array}{c}4 \\
5,6 \pm 2,7 \% \\
P>0,05\end{array}$ & $\begin{array}{c}4 \\
5,6 \pm 2,7 \% \\
P>0,05\end{array}$ & $\begin{array}{c}16 \\
22,5+5 \% \\
\mathrm{P}>0,05\end{array}$ \\
\hline & $31-36$ & $\begin{array}{c}2 \\
2,8 \pm 2 \% \\
P<0,01\end{array}$ & $\begin{array}{c}1 \\
1,4 \pm 1,4 \% \\
\mathrm{P}>0,05\end{array}$ & $\begin{array}{c}18 \\
25,4+5,2 \% \\
P>0,05\end{array}$ \\
\hline \multicolumn{2}{|c|}{ Total } & $\begin{array}{c}13 \\
18,3+4,6 \%\end{array}$ & $\begin{array}{c}13 \\
18,3+4,6 \%\end{array}$ & $\begin{array}{c}45 \\
63,4+5,7 \% \\
\end{array}$ \\
\hline
\end{tabular}

*P - confidence indicator

It is established that as the stages of AN progress, in particular primary, anorectic and cachectic, the proportion of people with GP increases. Thus, if it was $14.7 \%$ at the initial stage of AN, and reached $20 \%$ at the anorectic stage, then it was already $42.7 \%$ at the cachectic stage (Fig. 5.).

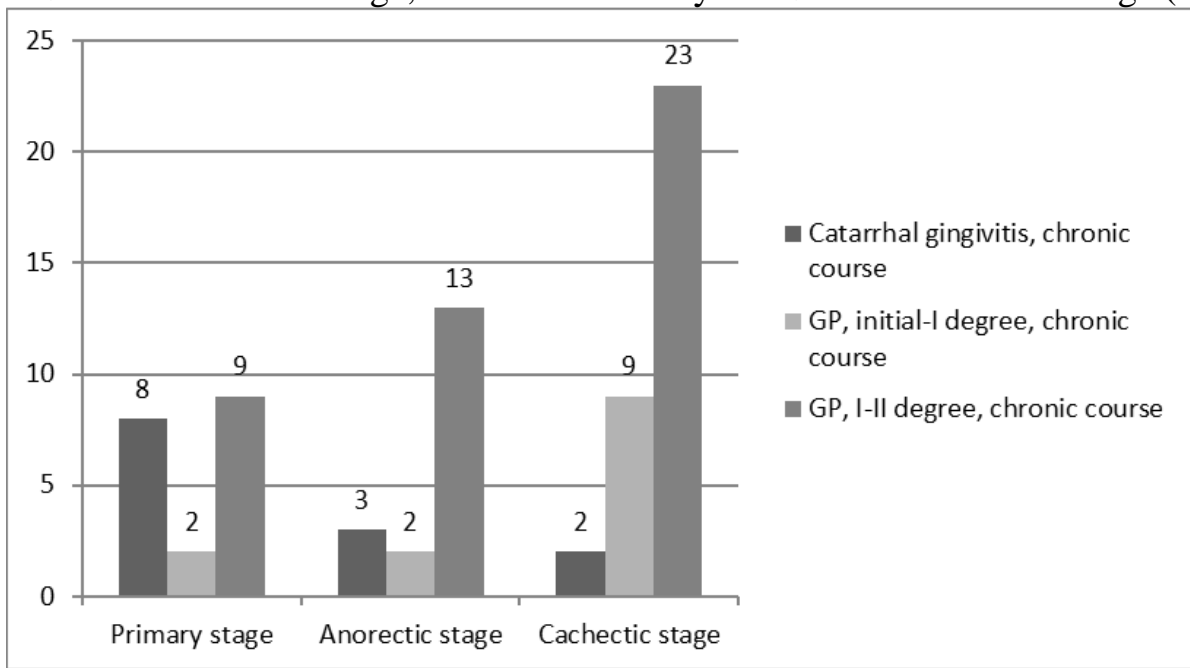

Fig. 5. Influence of stages of anorexia nervosa on the frequency of generalized parodontal diseases

The results of the study showed no correlation between the duration of NA and the independent forms of gingivitis, but a direct dependence of the underlying disease and GP was found more with accentuation for the duration of 9-12 years (table 2).

Table 2. Influence of the duration of anorexia nervosa on the manifestation of generalized periodontal diseases

\begin{tabular}{|c|c|c|c|c|}
\hline \multirow{2}{*}{$\begin{array}{c}\text { Duration of anorexia } \\
\text { nervosa, years }\end{array}$} & \multirow{2}{*}{$\begin{array}{l}\text { The } \\
\text { number of } \\
\text { patients }\end{array}$} & \multirow{2}{*}{$\begin{array}{l}\text { Catarrhal gingivitis, } \\
\text { chronic course }\end{array}$} & \multicolumn{2}{|c|}{ Generalized parodontal diseases } \\
\hline & & & $\begin{array}{l}\text { GP, initial-I degree, } \\
\text { chronic course }\end{array}$ & $\begin{array}{l}\text { GP, I-II degree, } \\
\text { chronic course }\end{array}$ \\
\hline $1-3$ & 15 & $\begin{array}{c}4 \\
5,6 \pm 2,7 \% \\
\mathrm{P}>0,05\end{array}$ & $\begin{array}{c}3 \\
4,2 \pm 2,4 \% \\
\mathrm{P}>0,05\end{array}$ & $\begin{array}{c}8 \\
11,3 \pm 3,8 \% \\
P>0,05\end{array}$ \\
\hline $4-8$ & 19 & $\begin{array}{c}5 \\
7 \pm 3 \% \\
P>0,05\end{array}$ & $\begin{array}{c}3 \\
4,2 \pm 2,4 \% \\
P>0,05\end{array}$ & $\begin{array}{c}11 \\
15,5 \pm 4,3 \% \\
\mathrm{P}>0,05\end{array}$ \\
\hline $9-12$ & 37 & $\begin{array}{c}4 \\
5,6 \pm 2,7 \% \\
\mathrm{P}<0,01\end{array}$ & $\begin{array}{c}7 \\
9,9 \pm 3,5 \% \\
P>0,05\end{array}$ & $\begin{array}{c}26 \\
36,6+5,7 \% \\
P>0,05\end{array}$ \\
\hline \multicolumn{2}{|l|}{ Total } & $\begin{array}{c}13 \\
18,3+4,6 \% \\
\end{array}$ & $\begin{array}{c}13 \\
18,3 \pm 4,6 \%\end{array}$ & $\begin{array}{c}45 \\
63,4 \pm 5,7 \% \\
\end{array}$ \\
\hline
\end{tabular}

As a result of our study, we have formed a view regarding the interaction of affiliation and comorbidity of generalized periodontal diseases and anorexia nervosa (fig. 6). 


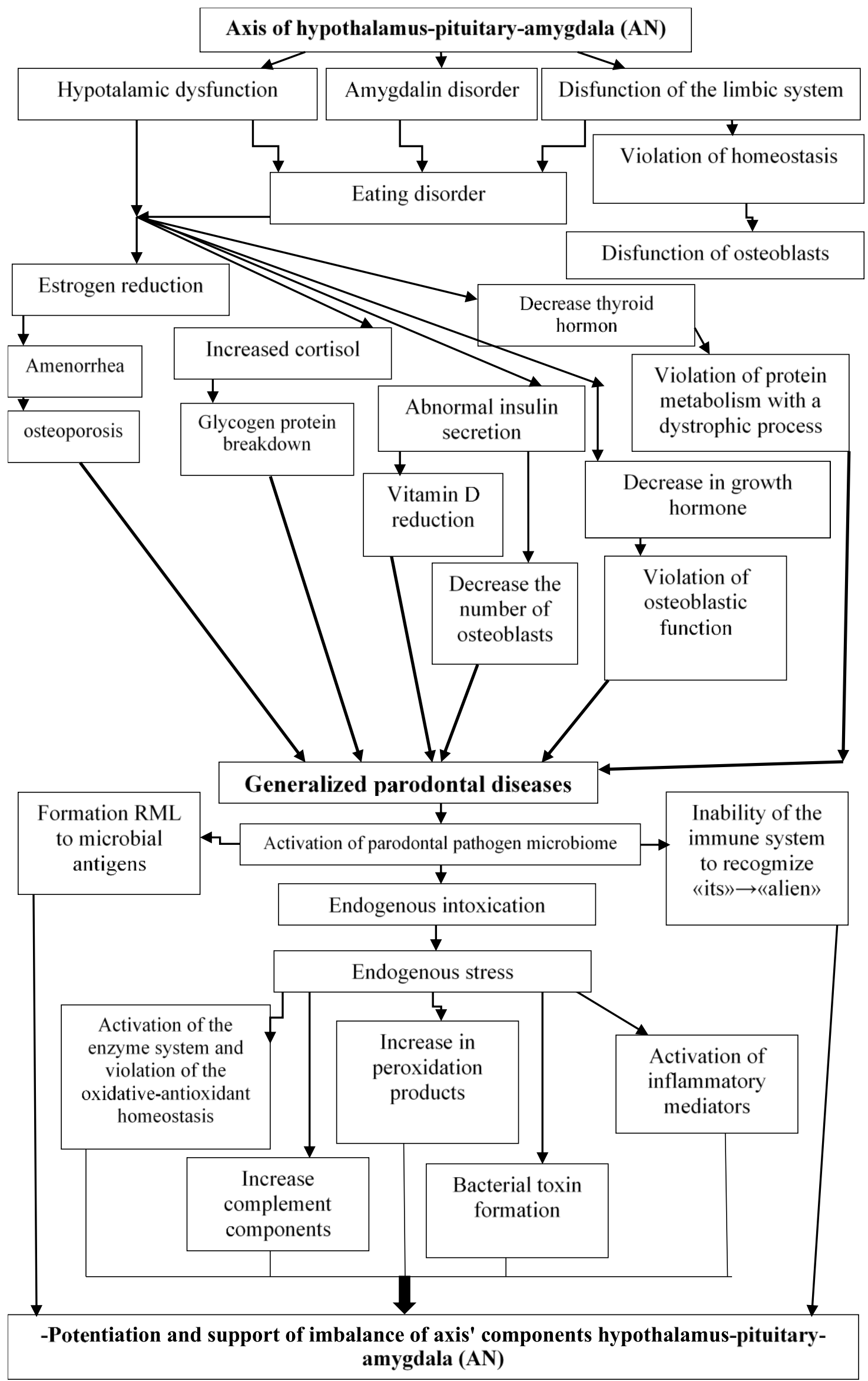

Fig. 6 


\section{Conclusions.}

1. A high incidence of periodontal disease was established, reaching $100 \%$ in patients with anorexia nervosa.

2. Among the independent forms of gingivitis, the most common was chronic catarrhal gingivitis with an emphasis on the marginal gums in patients with anorexia nervosa.

3. It is established that generalized parodontitis prevails over other forms of GPD $(80 \pm 4.6 \%)$, mainly I-II degrees, chronic course in patients with anorexia nervosa.

4. The influence of age on the frequency of generalized periodontal diseases has been established. The severity of GP was directly dependent on the age of patients with AN.

5. The course of GP was directly dependent on the age of patients with AN.

6. The relationship between the main clinical and radiological manifestations of generalized parodontitis from the duration and stage of nerve anorexia (primary $\rightarrow$ anorectic $\rightarrow$ cachectic) was established.

7. The hypothesis of a probable paradigm of interdependence of GPD and AN as affiliated diseases is proposed as the first stage of further development of this direction.

\section{REFERENCES}

1. Borysenko A. V., Sidel'nikova L. F., Antonenko M. Yu. Praktychna parodontolohiia [Practical Periodontology]. Kyiv: Doktor-Mediia, 2011, 472 p. [in Ukrainian].

2. VOZ za 60 let: khronolohyia osnovnykh sobytyj v oblasty obschestvennoho zdravookhranenyia [WHO for 60 years: chronology of major public health events]. WHO, 2008, 5 p. [in Russian].

3. Pavlenko O. I., Antonenko M. Yu., Sidel'nikov P. V. Planuvannia likuval'no-profilaktychnoi dopomohy khvorym z heneralivzoanym parodontytom na osnovi otsinky ryzyku urazhennia parodonta [Planning of medical and preventive care for patients with generals on a periodontal disease based on the evaluation of the risk of periodontal disease] Sovremennaia stomatolohyia, 2009, №1, pp. 56-60. [in Ukrainian].

4. Ohlrich E. J. The immunopathogenesis of periodontal disease / E. J. Ohlrich, M.P. Cullinan, G.J. Seymour // Aust. Dent. J. - 2009. - Vol. 54, Suppl. 1. - P. 2-10.

5. Povorozniuk V. V., Mazur Y. P. Kostnaja sistema i zabolevanija parodonta [Bone structure and periodontal disease]. Kyiv: Kniga Pljus, 2004 [in Ukrainian].

6. Hoek HW. Incidence, prevalence and mortality of anorexia nervosa and other eating disorders. Curr Opin Psychiatry. $2006 \mathrm{Jul} ; 19(4): 389-94$.

7. El Ghoch M, Milanese C, Calugi S, Pellegrini M, Battistini NC, Dalle Grave R. Body composition, eating disorder psychopathology, and psychological distress in anorexia nervosa: a longitudinal study. Am J Clin Nutr. 2014 Apr;99(4):771-8. doi: 10.3945/ajcn.113.078816.

8. Arcelus J, Witcomb GL, Mitchell A. Prevalence of eating disorders amongst dancers: a systemic review and meta-analysis. Eur Eat Disord Rev. 2014 Mar;22(2):92-101. doi: 10.1002/erv.2271.

9. Zaina F, Pesenti F, Persani L, Capodaglio P, Negrini S, Polli N. Prevalence of idiopathic scoliosis in anorexia nervosa patients: results from a cross-sectional study. Eur Spine J. 2018 Feb;27(2):293-297. doi: 10.1007/s00586-017-5181-9.

10. Jagielska GW, Przedlacki J, Bartoszewicz Z, Racicka E. Bone mineralization disorders as a complication of anorexia nervosa - etiology, prevalence, course and treatment. Psychiatr Pol. 2016;50(3):509-20. doi: $10.12740 / \mathrm{PP} / 59289$.

11. Mustelin L, Silén Y, Raevuori A, Hoek HW, Kaprio J, Keski-Rahkonen A. The DSM-5 diagnostic criteria for anorexia nervosa may change its population prevalence and prognostic value. J Psychiatr Res. 2016 Jun; 77:85-91. doi: 10.1016/j.jpsychires.2016.03.003.

12. Goh KH, Lee EL. Prevalence of abnormal liver function tests and comorbid psychiatric disorders among patients with anorexia nervosa and eating disorders not otherwise specified in the anorexia nervosa DSMIV criteria. Singapore Med J. 2015 Sep;56(9):488-92. doi: 10.11622/smedj.2015132.

13. Hofman M, Landewé-Cleuren S, Wojciechowski F, Kruseman AN. Prevalence and clinical determinants of low bone mineral density in anorexia nervosa. Eur J Intern Med. 2009 Jan;20(1):80-4. doi: 10.1016/j.ejim.2008.04.016. 